\title{
Socio-Cultural and Economic Impediments of Inequality in Provision of Educational Right to Female: A Case of Southern Punjab (Pakistan)
}

\author{
Tehmina Sattar \\ Department of Sociology, \\ Bahauddin Zakariya University, Multan (Pakistan) \\ Email: teminasattar@hotmail.com \\ Ghulam Yasin \\ Department of Sociology, \\ Bahauddin Zakariya University, Multan (Pakistan) \\ Email: miannyasin@yahoo.com \\ Phone: +92-61-9210448 \\ Saima Afzal \\ Department of Sociology, \\ Bahauddin Zakariya University, Multan (Pakistan)
}

Accepted: December 17, 2011 Published: February 03, 2012

Doi:10.5296/ijhrs.v2i1.1210

URL: http://dx.doi.org/10.5296/ijhrs.v2i1.1210

\begin{abstract}
Inequality in provision of educational right to girls is the leading rationale of their exclusion from the mainstream. If the marginalized sections of the society such as minorities, disabled and girls are given education as their indispensable human right then this will escorts towards their social inclusion in education sector. Enrollment ratios of girls lag far behind than boys at all levels of education in Pakistan. Worldwide literacy rates for adult men far exceed from women. Education enhances labor market productivity and income growth, yet educated women have beneficial effects on social well-being of the family. The social benefits from women's education ranges from fostering economic growth to extending the average life expectancy among female population. Despite these facts the issue of educational
\end{abstract}


right for girls has been denied in the educational policies of Pakistan since 1947. In Pakistan women have to face biasness in acquiring quality education. Gender discrimination is explicit from Economic Survey of Pakistan (2010) where the men are 65\% literate and the women are 45\% literate. In Southern Punjab (Pakistan) rigid cultural patterns, poverty, prejudice, stereotypic expectations from girl's education, restricted movement of girls, precarious traveling and lack of female teachers confines the girls from acquiring quality education. The respondents $(N=600)$ were interviewed from affiliated schools $(n=100$ out of $N=520)$ from BISE through multistage sampling technique from Multan and Khanewal districts. The results of the research illustrated that parental preference to boys education, rigid cultural patterns, cost of schooling (direct and indirect) and low socio-economic status of the parents were the foremost determinants of social exclusion of girls from education sector of Southern Punjab (Pakistan). Despite these determinants family size, prejudice, patriarchal structure of society, limited involvement of girls in decision making process and rigid values allied with girls education are the major constraints that restricted the access of girls from education sector of Southern Punjab (Pakistan).

Keywords: Educational rights, Inequality, Gender discrimination, Cultural patterns, Poverty, Pakistan.

\section{Introduction}

In accordance with Universal Declaration of Human rights Article 26 (1948) "Everyone has the right of education. Education shall be free at least in the elementary and fundamental stages. Technical and professional education shall be made generally available and higher education shall be equally accessible to all on the basis of merit." But regrettably girls have always been unrepresented in education sector of Pakistan as compared to boys. This gender disparity is evident from the fact that in 2006 only 14 million girls have been studying at primary level as compared to 18.3 million boys (Lyned, 2007). Educational status of women in Pakistan is alarmingly low. Only $19 \%$ females are literate up to Metric level, $8 \%$ to intermediate, $5 \%$ to Bachelors and $1.4 \%$ to Masters stage. Therefore $60 \%$ adult female population is illiterate. Consequently out of 3.3 million (out of school) population, 2.503 million encompass of females (Aly, 2007) (p.28). Overall the literacy rate of Pakistan is 57\% (69\% for males and $45 \%$ for females). Literacy remains higher in urban areas (74\%) than in rural areas (48\%). Literacy rate for men is (69\%) and for women is (45\%) (Pakistan Social and Living Standards Measurement Survey (PSLM), 2008-2009). Girls are also deprived from their basic educational right. Approximately $76 \%$ female adult population is illiterate. On the other hand $75 \%$ female students drop out at the primary level. The gender disparity is flagrant from the fact that $57 \%$ primary school age girls attend school as compared to $89 \%$ boys (Mehbob-ul-Haq, 2000). Gender Parity Indices for adult literacy rate rose from 0.51 in 2001-02 to 0.58 in 2005-06 and 0.64 in 2007-08. GPI for youth literacy rate remained at the same level of 0.72 in both periods of 2001-02 and 2005-06, which perk up to 0.78 in 2007-08. Females are underrepresented in rural areas (36\% for rural areas versus $43 \%$ for urban areas), a feature that holds for secondary education (35\% for rural and $48 \%$ for urban areas). Female teachers are 47\% of primary school teachers in 2005-06 (National Education Census, 2006). 
Although Southern Punjab (Pakistan) inspires the world in terms of innovation, experimentation and dynamic approaches to development and change but yet various barricades to girls education limited its effectiveness (Mishra, 2005). At Millennium Summit, the world community declared to endorse gender equality and choose an explicit target about achievement of gender equity in primary and secondary education by the year 2005 in every country of the world by crack down on various challenges faced by South Asian countries (Abu-Ghaida and Klasen, 2004). Therefore South Asians educational challenge of low quality girls education consists of six major tasks: 1) Enrolling all children in primary schools 2) Improving the quality and relevance of education 3) Provision of well qualified teachers 4) Removing gender disparities 5) Building relevant technical skills and 6) Mobilizing the adequate financial resources. The major rationale of education is to endow with equity in the distribution of educational services (Jam, 2005) (chapter, 6).

\begin{tabular}{|c|c|c|}
\hline \multicolumn{3}{|c|}{$\begin{array}{l}\text { Year wise comparison of literacy rate between males and females from } \\
1999-2009\end{array}$} \\
\hline Year & Male & Female \\
\hline 1999 & $59.2 \%$ & $32.2 \%$ \\
\hline $2000-01$ & $62.8 \%$ & $34.5 \%$ \\
\hline $2004-05$ & $65 \%$ & $40 \%$ \\
\hline $2005-06$ & $65 \%$ & $42 \%$ \\
\hline 2006-07 & $67 \%$ & $42 \%$ \\
\hline $2007-08$ & $69 \%$ & $44 \%$ \\
\hline 2008-09 & $69 \%$ & $45 \%$ \\
\hline \multicolumn{3}{|c|}{$\begin{array}{l}\text { Pakistan Social and Living Standard Surveys (PSLM) 2006-07, } \\
\text { 2007-08 }\end{array}$} \\
\hline
\end{tabular}

Education augments the socio-political and economic adjustment of every individual in the society (Shami, et al. 2005). History has witness that no nation has been able to accelerate in terms of development without taking into consideration education as prerequisite for sustainable development (Jam, 2005). But there are many constraints that detached the girls from acquiring quality education. These obstructions can only be detached through long term policies to bring about cultural and attitudinal change to augment the enrollment rate and diminish the dropout rates for girls (Heise, et al. 1999). Female education has positive impact on development of the country. Higher ratio of educated women amplifies per capita income of the country (Stephen, 2002). The importance of girls education can be augmented through MDG's that embattled to eliminate the gender disparity by 2005 and accomplish gender equality by 2015 so that women have full access to education (Khalid and Mukhtar, 2002). 


\begin{tabular}{|l|l|l|l|l|l|l|l|l|l|}
\hline Region/Province & \multicolumn{2}{|l}{$\mathbf{2 0 0 5 - 2 0 0 6}$} & $\mathbf{2 0 0 6 - 2 0 0 7}$ & \multicolumn{2}{l|}{$\mathbf{2 0 0 7 - 2 0 0 8}$} \\
\hline & Male & $\begin{array}{l}\text { Femal } \\
\text { e }\end{array}$ & Both & Male & $\begin{array}{l}\text { Fema } \\
\text { le }\end{array}$ & Both & Male & $\begin{array}{l}\text { Femal } \\
\text { e }\end{array}$ & Both \\
\hline $\begin{array}{l}\text { Urban areas } \\
\text { (overall) }\end{array}$ & $\mathbf{7 9}$ & $\mathbf{6 4}$ & $\mathbf{7 1}$ & $\mathbf{7 9}$ & $\mathbf{6 5}$ & $\mathbf{7 2}$ & $\mathbf{8 0}$ & $\mathbf{6 3}$ & $\mathbf{7 1}$ \\
\hline Punjab & 80 & 67 & 73 & 79 & 68 & 73 & 78 & 66 & 72 \\
\hline Sind & 80 & 65 & 72 & 80 & 65 & 73 & 81 & 64 & 73 \\
\hline KP & 73 & 45 & 59 & 75 & 46 & 61 & 79 & 51 & 64 \\
\hline Baluchistan & 77 & 40 & 59 & 76 & 42 & 61 & 84 & 41 & 64 \\
\hline $\begin{array}{l}\text { Rural } \\
\text { (overall) }\end{array}$ & $\mathbf{5 7}$ & $\mathbf{3 1}$ & $\mathbf{4 4}$ & $\mathbf{6 0}$ & $\mathbf{3 0}$ & $\mathbf{4 5}$ & $\mathbf{6 4}$ & $\mathbf{3 4}$ & $\mathbf{4 9}$ \\
\hline Punjab & 58 & 37 & 47 & 61 & 38 & 50 & 66 & 40 & 53 \\
\hline Sind & 54 & 17 & 37 & 52 & 16 & 36 & 57 & 20 & 40 \\
\hline KP & 62 & 27 & 44 & 65 & 24 & 44 & 65 & 29 & 46 \\
\hline Baluchistan & 46 & 13 & 31 & 52 & 15 & 35 & 58 & 16 & 39 \\
\hline Pakistan Social and Living Standard Surveys (PSLM) 2006-07, 2007-08 & \\
\hline
\end{tabular}

Despondently one of the major concentrations of illiterates in Pakistan is women (Chaudhry, 2005). In Pakistan low literacy rate is an outcome of various barriers in education sector like overcrowded classes, absence of indispensable classroom materials, lack of drinking water, lack of sanitary facilities and inappropriate teachers training (Vachon, 2007). In spite of these obstructions the other stumbling block of education sector is gender discrimination with women in acquiring education. Quality of girls education in schools is the imperative trait that influences the decision making of the parents to enroll their girls to school but for the boys quality does not matter because the parents are already more focused on boy's education than girl's education (Lloyed, et al. 2005).

\begin{tabular}{|l|l|}
\hline Non-market and external benefits of girls education \\
\hline Benefit type & Findings \\
\hline $\begin{array}{l}\text { Childcare } \\
\text { education }\end{array}$ & $\begin{array}{l}\text { Mothers schooling affects child schooling level and their educational } \\
\text { achievements }\end{array}$ \\
\hline Child health & Children health is positively related to mothers education \\
\hline Fertility & Mothers education is inversely related to birth rate \\
\hline $\begin{array}{l}\text { Mothers own } \\
\text { health }\end{array}$ & \begin{tabular}{l} 
Increase in education increases life expectancy of mothers \\
\hline Spouse health
\end{tabular} \\
$\begin{array}{l}\text { Increase in education increase awareness about spouse health and increase } \\
\text { life expectancy }\end{array}$ \\
\hline Source: Based on Wolfe and Zuvekas, 1997. \\
\hline
\end{tabular}

Education can augment the women competencies by breaking their vicious cycle of poverty, discrimination and exploitation (Verma, 2006). But yet there are various barriers to 
girls education and these barriers encompass varied supply and demand side factors such as obstinate cultural patterns, opportunity costs verses lower rate of returns for girls, female headed households, lack of incentives for girls education, non-fulfillment of beurocratic promises about gender equality in education sector and safety concerns for girls (Addy, 2008). Negative attitudes in the form of social discrimination can initiate serious educational barriers. Despite that lack of awareness and traditional prejudices are also the major social constraints that obstruct the process of development in education sector of Pakistan. Girlhood is culturally mute and girls have little preference for education attainment, employment opportunities, choice of husband, level of awareness and poor self concept that detains their aspirations. Decision making of girls is limited due to lack of access to resources including finance, low education levels and limited mobility due to cultural restrictions (UNESCO, 2006). Conservative attitude of the family especially in the rural areas deprives the girls from acquiring quality education (Iredale and Guo, 2004). Conversely direct and indirect cost of schooling like school uniforms, schools books, low parental income and labor contribution are the cost of schooling that divests the girls from getting quality education (Boyle, et al. 2002).

Since 1947 various policies, projects and schemes have been formed related to girls education in Pakistan but they are deficient to meet the needs for girls education. The major projects that address the issue of girls education are TAWANA Pakistan Programme, Monetary Support Programme, Free distribution of Textbooks, Rural and Urban Fellowship Programmes and Community Support Process. These schemes are operational in the rural and urban areas and they have allied with Multi Donor Support unit such as World Bank (Qureshi, 2004).

\begin{tabular}{|c|c|c|c|c|}
\hline \multicolumn{5}{|c|}{ Universal Primary Education (UPE) Targets } \\
\hline Policies & Targets & Boys & Girls & Gender gap \\
\hline New Education Policy (1970) & $\begin{array}{l}\text { Universal Enrollment } \\
\text { up to class } 5 \text { by } 1980\end{array}$ & ---- & ---- & NA \\
\hline $\begin{array}{lll}\begin{array}{l}\text { National } \\
(1972-1980)\end{array} & \text { Education } & \text { Policy } \\
\end{array}$ & $\begin{array}{l}\text { Universal primary } \\
\text { education }\end{array}$ & 1979 & 1984 & 5years \\
\hline National education policy (1979) & $\begin{array}{l}\text { Universal primary } \\
\text { education }\end{array}$ & 1987 & 1992 & 5years \\
\hline Sixth five year plan (1983-1998) & $\begin{array}{l}\text { Universal primary } \\
\text { education }\end{array}$ & 1986 & 1988 & 2years \\
\hline Seventh five year plan (1983-1988) & $\begin{array}{l}\text { Universal primary } \\
\text { education }\end{array}$ & 1992 & 1992 & - \\
\hline $\begin{array}{lll}\text { National } & \text { Education } & \text { Policy } \\
(1992-1997) & & \end{array}$ & $\begin{array}{l}\text { Universal primary } \\
\text { education }\end{array}$ & 2002 & 2005 & 3years \\
\hline $\begin{array}{lll}\text { National } & \text { Education } & \text { Policy } \\
(1998-2010) & & \end{array}$ & $\begin{array}{l}\text { Universal primary } \\
\text { education }\end{array}$ & 2005 & 2010 & 5years \\
\hline
\end{tabular}


National Plan for Action of Education for All (2001-2005) focused on Early Childhood Education, elementary education and adult education. UNESCO (2010) divulge that public and private sector have failed to expand the service delivery relative to the potential demand. Conversely blockades regarding education encompass gender inequalization, rigid family decisions to send their daughters to schools, inadequate school infrastructure, lack of quality education, cost of schooling, school proximity, cultural constraints and attitude of underprivileged people to send their daughters to schools (Andrabi, et al. 2007). Education has suffered from various obstructions that creates the hurdle in policy success like underinvestment in education sector, failure to implement five year plans, lack of purpose, poor infrastructure where the schools lack basic facilities (such as classrooms, toilets, blackboards and furniture), lack of qualified female teachers, high dropout rates of girls, non-effective policy implementation strategies, lack of school autonomy, immature managerial capacity and stereotypic behavior of the society (Qureshi, 2004). Government of Pakistan has been taken diverse initiatives regarding the Social Sector Reforms (SSR). They include National Education Policy (1998-2010), Education Sector Reforms (ESR) (2001-2006), Education for All (2015), Ten Years Perspective Development Plan (2001-2011), National Commission for Human Development (NCHD), Poverty Reduction Strategy Papers (PRSP) and Medium Term Development Framework (MTDF) (2005-2010). These multiple programs were working together within Pakistan to alleviate problems of low literacy rate especially allied with girls education (National Education Policy, 2009). Medium Term Development Framework (2005-2010) ensures the equitable development in all regions of Pakistan. It illustrates various challenges in schools and the foremost targets of MTDF are to accomplish Universal Primary Education (UPE), endorsement of gender equality, girls empowerment through education, free education up to secondary level and introduction of vocational education for girls (Akram and Khan, 2007).

\begin{tabular}{|l|l|l|l|}
\hline MTDF (2010) and MGD (2015) Targets & $\begin{array}{l}\text { Benchmark } \\
\mathbf{2 0 0 4 - 2 0 0 5}\end{array}$ & MTDF 2010 & MGD's 2015 \\
\hline Category & 56 & 77 & 88 \\
\hline Literacy rate (population 10+) & 62 & 85 & 89 \\
\hline Total & 44 & 66 & 87 \\
\hline Male & Female & 80 & 100 \\
\hline Youth literacy rate (population 15-24) & 90 & 100 \\
\hline Total & 66 & 70 & 100 \\
\hline Male & 79 & 0.94 & 1.00 \\
\hline Female & 52 & 0.90 \\
\hline Gender Parity Index (GPI) & 0.80 & 0.94 \\
\hline Primary education & 0.72 & \\
\hline Secondary education & \multicolumn{3}{|l|}{} \\
\hline Source: Akram and Khan, 2007. Pakistan Institute of Development Economics(PIDE) \\
\hline
\end{tabular}




\section{Purpose of the study}

The present study is premeditated to investigate the role of education in proficient and equitable development process. Besides this, the researcher also decomposes socio-cultural and economic impediments that are responsible for exclusion of girls from educational right in Southern Punjab (Pakistan). Previous studies address diverse constraining factors for social exclusion of girls from education sector like rampant gender disparities, low quality girls education and their low enrollment rate. But this study endow with ample literature about these issues in the broader spectrum. This paper also bestows a concise review of the progressive measures, incentive schemes and education policy making for the development of gender supportive projects. Imperative questions which were addressed in the course of this study include:

1) What are the trends in the past that promote gender disparity and limited the access of girls to education sector in Southern Punjab (Pakistan)?

2) What are the major socio-cultural and economic impediments of development for girls in education sector of Southern Punjab (Pakistan)? To what extent these blockades are accountable for exclusion of girls from education sector of Southern Punjab (Pakistan)?

3) What are the major policies that have been designed to increase the literacy rate of girls in Southern Punjab (Pakistan)? To what extent these policies are affluent in achieving their targets?

4) What are the major policy implications for social exclusion of girls from education sector of Southern Punjab (Pakistan)?

\section{Methods and Procedures}

The social setup of Southern Punjab (Pakistan) expected traditional household roles from women therefore the aspirations, achievements and preferences of the women are always neglected. This study used cross sectional survey research design to illustrate the influence of various socio-cultural and economic impediments on social exclusion of girls from education sector of Southern Punjab (Pakistan).

\section{Sample size and sampling procedure}

This study targeted all the parents, teachers and female students of Southern Punjab (Pakistan). A sample of $\mathrm{N}=600$ respondents ( $\mathrm{n} 1=200$ teachers, $\mathrm{n} 2=200$ parents and $\mathrm{n} 3=200$ female students) was selected from affiliated schools of two districts (Khanewal and Multan district) from Southern Punjab (Pakistan). Out of N=520 affiliated schools from BISE n=100 affiliated schools were opted randomly from Multan and Khanewal districts through multistage sampling technique. Multan and Khanewal districts were selected purposively as they have the lowest growth of literacy rate i.e. $4.3 \%$ and $4.8 \%$ respectively.

\section{Instrument}

The researcher used interview schedule as a tool for data collection procedure. The questions were designed to evaluate the possible socio-cultural and economic impediments that are responsible for social exclusion of girls from education sector of Southern Punjab. The interview schedule was divided in three portions that comprise of 164 questions. The first portion addressed various demographic and structural questions pertaining to female 


\section{Macrothink

students. On the other hand the second portion addressed various socio-cultural and economic impediments in education sector of Southern Punjab (Pakistan). While the last portion addressed the determinants of policy failure regarding girl's education. The researcher compares different responses of the three stakeholders on pre-coded 5 likert attitudinal scale. Both structured and unstructured questions were used to get maximum response rate. The data was coded by using SPSS software (version 17).

\section{Data analysis:}

The researcher used ANOVA test to evaluate responses of three stakeholders (as difference between three means) and to avoid the response effects such as wordings, order and format of the questions. The researcher investigates the explanatory relationship among the dependent and independent variables by the application of one way ANOVA test (Joshua, et al. 2006). The values were calculated by the researcher for six independent variables (such as low status of the women in socio-political and economic sphere, Intra-household child labour patriarchal structure, conservative attitude of the family and community, preference to boys education as well as direct and indirect cost of schooling). $\mathrm{P}$ values illustrated that alternate hypothesis is accepted as there is significant difference among the opinions of three stakeholders. The formula for one way ANOVA is as follows:

$$
\begin{aligned}
& S S_{\text {towal }}=\left(\sum x_{1}{ }^{2}+\sum x_{2}{ }^{2}+\ldots \sum_{r}{ }^{2}\right)-\frac{\left(\sum x_{1}+\sum x_{2}+\ldots \sum x_{r}\right)}{N} \\
& S S_{\text {toule }}=\left[\frac{\left(\sum x_{1}\right)^{2}}{n_{1}}+\frac{\left(\sum x_{2}\right)^{2}}{n_{2}}+\ldots \frac{\left(\sum x_{r}\right)^{2}}{n_{r}}\right]-\frac{\left(\sum x_{1}+\sum x_{2}+\ldots x_{r}\right)}{N} \\
& \mathrm{SS}_{\text {within }}=\mathrm{SS}_{\text {total }}-\mathrm{SS}_{\text {among }} \\
& \mathrm{df}_{\text {among }}=\mathrm{r}-1 \quad \mathrm{df}_{\text {within }}=\mathrm{N}-\mathrm{r}
\end{aligned}
$$

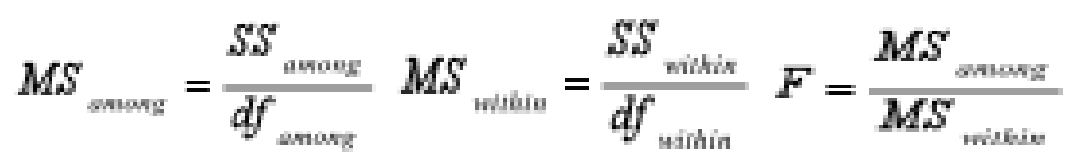


Table No. 1

2012, Vol. 2, No. 1

Percentage distribution of respondents with respect to socio-cultural and economic blockades to girls education.

\begin{tabular}{|l|l|l|l|}
\hline \multirow{2}{*}{ Socio-cultural and economic blockades to girls education } & \multicolumn{3}{l}{$\begin{array}{l}\text { Percentage of respondents agree } \\
\text { on these variables }\end{array}$} \\
\cline { 2 - 4 } & Teachers & Parents & Students \\
\hline Limited involvement of girls in decision making process & $60.5 \%$ & $22.5 \%$ & $40.5 \%$ \\
\hline Low socio-economic status of the women & $58.5 \%$ & $50 \%$ & $52 \%$ \\
\hline Prejudice for girls education & $59 \%$ & $41.5 \%$ & $60.5 \%$ \\
\hline Gender discrimination & $60.5 \%$ & $17 \%$ & $52 \%$ \\
\hline Patriarchal structure of the society & $70 \%$ & $30.5 \%$ & $31 \%$ \\
\hline Dependency of the women on head of household & $62.5 \%$ & $38.5 \%$ & $61 \%$ \\
\hline $\begin{array}{l}\text { Value expectations with girls (such as modesty, veiling and } \\
\text { purity etc) }\end{array}$ & $52 \%$ & $38 \%$ & $63.5 \%$ \\
\hline $\begin{array}{l}\text { Conservative attitude of the family and community towards } \\
\text { girls education }\end{array}$ & $66 \%$ & $54 \%$ & $51 \%$ \\
\hline Religious leaders wrong propaganda about girls education & $59 \%$ & $39.5 \%$ & $51.5 \%$ \\
\hline Cultural biasness about girls education & $27.5 \%$ & $35.5 \%$ & $50.5 \%$ \\
\hline Gender role stereotypes & $59.5 \%$ & $45 \%$ & $57.5 \%$ \\
\hline Parental preference to boys education & $69 \%$ & $54 \%$ & $70 \%$ \\
\hline Gender discrimination with female teachers & $65 \%$ & $49 \%$ & $60.5 \%$ \\
\hline Low quality education for girls & $59.5 \%$ & $27 \%$ & $59 \%$ \\
\hline Lack of separate schools for girls & $55.5 \%$ & $64 \%$ & $48 \%$ \\
\hline Girls child labor (Intra-household and Extra-household) & $21 \%$ & $28.5 \%$ & $46 \%$ \\
\hline Biased household school choice for girls & $61.5 \%$ & $35.5 \%$ & $74.5 \%$ \\
\hline Cost of schooling (direct and indirect) & $58 \%$ & $24.5 \%$ & $70 \%$ \\
\hline
\end{tabular}

\section{Discussion:}

There is always gender discrimination with girls regarding literacy rate due to conservative attitude of the people in rural areas, rigid cultural patterns, cost of schooling and non-realization of the importance of education (Shaukat, 2009). The above mentioned table demonstrates that $58 \%$ teachers, $24.5 \%$ parents and $70 \%$ students agree that cost of schooling is the foremost constraint that is responsible for social exclusion of girls from education sector. On the other hand $21 \%$ teachers, $28.5 \%$ parents and $46 \%$ students agree that child labor (Intra household and Extra household) is the major determinant of social exclusion of girls from education sector. When the household is incapable to meet the expense of girls schooling then viscous cycle is perpetuated that divests the women to contribute their efforts in income generation for the household. Girls access to school is entirely dependent upon the decision making of the head of household. There are strong values that are narrated with Muslim girls like modesty, veiling and submissiveness. Thus in absence of male head of the 
households girls are not permitted to attend school predominantly when the distance of school is outsized (Jejeebhoy and Sathar, 2001). It is evident from the above mentioned table that $52 \%$ teachers, $38 \%$ parents and $63.5 \%$ students have an opinion that value expectations with girls (such as purity, modesty, veiling, and submissiveness) are the foremost blockade to girls education. Girls are considered as marginalized component of the society. Hence they have always been deprived from equal participation in education sector and labor market. In Pakistan the literacy rate of youth (especially young girls) is relatively very low as compared to other South Asian countries. Only 53\% young females (aged 15-24 years) are literate as compared to $77 \%$ boys of the same age group (Lyned, 2007). Thus the table shows that $60.5 \%$ teachers, $17 \%$ parents and $52 \%$ students agree that gender discrimination is the major determinant responsible for social exclusion of girls from education sector. There are many household and school barriers and they predominantly affect girls. Large family size and low family income are the major determinants of high dropout rates of the children (especially girls) from school. Another factor of low enrollment rate of girls education is that boys education is given more importance than girls education. For boys school quality is measured by quality teachers in primary schools that extensively reduce the probability of dropping out from school. Good household income reduces the probability of dropout rate of children from schools (Llyod, 2009). Alternatively 27.5\% teachers, 35.5\% parents and 50.5\% students cited that cultural biasness is the foremost barricade to girls education. One of the major cultural obstructions is misinterpretation of Islamic standpoint about girls education. Approximately 96\% Pakistan population is Muslim but they are not able to have adequate access to education sector. Religious leaders make erroneous propaganda about girls education to be prohibited in Islam (Chitrakar, 2007). The table prop up this standpoint that 59\% teachers, $39.5 \%$ parents and $51.5 \%$ students agree that religious leaders wrong propaganda about girls education is the major blockade in social inclusion of girls to education sector of Southern Punjab (Pakistan). On the other hand $70 \%$ teachers, 30.5\% parents and 31\% students (patriarchal structure of Pakistani society), 62.5\% teachers, 38.5\% parents and $61 \%$ students (dependency of the women on the head of the household) agree that these blockades are responsible for social exclusion of girls from education sector of Pakistan. There are countless barricades related with girls education that mostly incorporate diverse obstinate cultural factors such as patriarchal structure of the society, stereotypic behavior related with girls education and prejudices about girls education. Other factors are narrated with security issues for girls like poor roads, restricted transportation, unsafe traveling and constrained movement of girls to education sector. These issues limited the access of girls to education sector of Pakistan (Qureshi, 2004). Consequently 58.5\% teachers, 50\% parents and 52\% students (low socio-economic status of the women in social, cultural, economic and political sphere), 59\% teachers, $41.5 \%$ parents and $60.5 \%$ students (prejudice for girls education), $60.5 \%$ teachers, $17 \%$ parents and 52\% students (gender discrimination) are the foremost obstructions responsible for social exclusion of girls from education sector. Grade attainment, current enrollment rate, withdrawal from school and diverse household effects are the major determinants of school completion for both boys and girls. But various cultural determinants turn down the enrollment rate of girls. These factors encompass rigid cultural patterns, gender role stereotypes, low parental education and lack of separate schools for girls (Glick and Sahn, 
2000). Consequently $59.5 \%$ teachers, $45 \%$ parents and $57.5 \%$ students agree that gender role stereotypes is the most crucial cause of low access of girls to education sector. Alternatively $55.5 \%$ teachers, $64 \%$ parents and $48 \%$ students agree that lack of separate schools for girls is the major rationale of social exclusion of girls from education sector of Pakistan. Fuller and Lipman (2004) scrutinized that certain ways of veiling, dress, purity and modesty are the characteristics of Muslim women but the government does not always encourage these acts especially when the Muslim women are living in foreign countries. It is prevalent cultural practice in Pakistan that boys are preferred to attain education than girls. Over and above $69 \%$ teachers, $54 \%$ parents and $70 \%$ students agree that preference to boys education is the foremost cultural blockade in girls education. This biasness is due to fear of lower rate of returns from girls education. There is always a noteworthy biasness regarding the investment on education of girls and boys. Correspondingly this biasness escorts towards differential type preference for both boys and girls. Accordingly the parents prefer to send their boys to private schools and girls to public schools and therefore girls endure low quality schooling than boys (Aslam, 2009). Thus 61.5\% teachers, 35.5\% parents and $74.5 \%$ students agree that biased household school choice limited the access of girls from education sector.

Table no. 2

H1: Low status of women in socio-cultural and economic sphere is the major determinant of low enrollment rate of girls.

\begin{tabular}{|l|l|l|l|l|l|}
\hline Source & DF & SS & MS & & \\
\cline { 1 - 4 } Factor & 2 & 81.94 & 40.97 & F & P \\
\cline { 1 - 4 } Error & 597 & 876.01 & 1.47 & 0.000 \\
\hline Total & 599 & 957.96 & & & \\
\cline { 1 - 4 }
\end{tabular}

$\mathrm{H} 2$ : High dropout rate of girls is the major outcome of Intrahousehold child labor.

\begin{tabular}{|l|l|l|l|l|l|}
\hline Source & DF & SS & MS & & \\
\cline { 1 - 4 } Factor & 2 & 218.57 & 109.29 & F & P \\
\cline { 1 - 4 } Error & 597 & 871.83 & 1.46 & 0.000 \\
\cline { 1 - 4 } Total & 599 & 1090.40 & & & \\
\hline
\end{tabular}

H:3 Patriarchal structure of Pakistani society has significant impact on enrollment rate of girls in education sector.

\begin{tabular}{|l|l|l|l|l|l|}
\hline Source & DF & SS & MS & & \\
\cline { 1 - 4 } Factor & 2 & 225.61 & 112.81 & F & P \\
\cline { 1 - 4 } Toror & 597 & 970.86 & 1.63 & 69.37 & 0.000 \\
\cline { 1 - 4 } & 599 & 1196.47 & & & \\
\hline
\end{tabular}

H: 4 Conservative attitudes of the family/community results in high dropout rate of girls from education sector of Pakistan.

\begin{tabular}{|c|c|c|c|c|c|}
\hline Source & DF & SS & MS & \multirow{4}{*}{$\begin{array}{l}\mathbf{F} \\
25.13\end{array}$} & \multirow{4}{*}{$\begin{array}{l}\mathbf{P} \\
0.000\end{array}$} \\
\hline Factor & 2 & 96.37 & 48.19 & & \\
\hline Error & 597 & 1144.82 & 1.92 & & \\
\hline Total & 599 & 1241.19 & & & \\
\hline
\end{tabular}




\section{Ml Macrothink}

\begin{tabular}{|c|c|c|c|c|c|}
\hline Source & DF & SS & MS & \multirow{4}{*}{$\begin{array}{l}\mathbf{F} \\
27.92\end{array}$} & \multirow{4}{*}{$\begin{array}{l}\mathbf{P} \\
0.000\end{array}$} \\
\hline Factor & 2 & 81.94 & 40.97 & & \\
\hline Error & 597 & 876.01 & 1.47 & & \\
\hline Total & 599 & 957.96 & & & \\
\hline \multicolumn{6}{|c|}{$\begin{array}{l}\text { H:6 Direct and indirect cost of schooling is the major determinant of high dropout rates among the } \\
\text { girls. }\end{array}$} \\
\hline Source & DF & SS & MS & \multirow{4}{*}{$\begin{array}{l}\mathbf{F} \\
93.17\end{array}$} & \multirow{4}{*}{$\begin{array}{l}\mathbf{P} \\
0.000\end{array}$} \\
\hline Factor & 2 & 262.29 & 131.15 & & \\
\hline Error & 597 & 840.37 & 1.41 & & \\
\hline Total & 599 & 1102.66 & & & \\
\hline
\end{tabular}

\section{Discussion:}

In Pakistan women have limited access to education sector therefore they are always at the lower end of educational ladder (Qureshi and Rarieya, 2007). Education alone cannot safe the girls from social exclusion from education sector but yet it plays an imperative role in making them empower in their social, cultural and economic life by giving them awareness (especially in patriarchal structure with conservative environment) about their legal rights (Kabeer, 2005). Boys are more preferred to acquire education because it is expected that they will peruse social mobility to facilitate the family expectations (Glandley, 2004). But there always exists gender gap in education sector as boys are more preferred to accomplish education than girls $(\mathbf{p = 0 . 0 0 0})$. A variety of obstructions associated with girls education are recurrently concerned with cultural and economic restraints. Women are deprived from education and have lowest literacy rate. Accordingly this marginalized component of the society becomes unskilled. Girls are divested from decision making about education and thus have little contribution in the economic sharing process because education attainment is directly related with economic sharing process (Klasen, 2002). On the other hand conservative parents mostly do not permit their daughters to take admission in co-education schools (Xu and Jaschok, 2009). Thus there are many blockades related with community in order to conserve the cultural distinctiveness of any women and the most imperative is the conservative reaction of the family and community towards their daughters education (p=0.000) (Benson, 2004). When women are given equal chance in decision making process then they can better utilize their education in making a phenomenal change in their status in socio-cultural and economic sphere. Thus squat status of the women divests them from decision making process and thus it is the major determinant of their low enrollment rate (p=0.000) (Sheikh, 2004). There are three major areas in education sector that should be explored because they have the dramatic effect on primary school access, type (private verses public) and quality of education because these factors influence the parental decisions to enroll their girls to school or not (Lloyed, et al. 2005). But there is always the discrimination between men and women in terms of treatment, wage and labor market returns. Despite this parents have supplementary investment rationale in allocating more resources towards boys education than girls education within households (Aslam, 2009). The most important barrier to girls education is uneven patterns of development. The women are also constrained to do the household domestic work. Girlhood is culturally mute and they have diminutive 
preference to education, employment, choice of husband, level of awareness and poor self concept that confines its aspirations. Decision making is restricted due to lack of access to resources including finance, low education levels, low skill levels and inadequate mobility due to cultural restrictions (Qureshi, 2004). The major barricade responsible for high dropout rates of girls from school is cost of schooling $(\mathbf{p = 0 . 0 0 0})$. Consequently school fees and the cost of textbooks are the two foremost economic constraints that decreased the enrollment rate of the girls. Parents mostly evade their daughters to be enrolled in schools because girls have been obligatory at home for labor. On the other hand girls require higher cost of schooling like (school books, school uniforms and transportation cost etc) (UNESCO, 2008). The incidence of child labor decreases the school enrollments of the students especially in the underdeveloped countries (p=0.000) (Edmont, 2002). Girls are mostly engaged in Intrahousehold child labor and boys are mostly engaged in extrahousehold child labor. Thus the incidence of child labor is common among the poor families where the vicious cycle engaged the children in Intrahousehold and Extrahousehold child labor. There are many supply and demand side barricades related with girls education that have the momentous impact on education sector. These obstructions integrate various socio-cultural and economic factors such as inclination of boys education over girls education, poverty, gender discrimination, rigid social and cultural values (such as patriarchal structure of the society) (p=0.000), direct and indirect cost of schooling (such as school fees and school uniforms) as well as transportation issues. On the other hand opportunity costs verses lower rate of returns e.g. girls are needed for household work, early marriages of girls, low level of parental literacy, single headed household especially female headed households, wrong insight about girls education and neglection of educational importance) are the diverse demand side factors that are mentioned by the researcher (Addy, 2008).

\section{Conclusion}

After revering the analysis the researcher concluded that female education is optimistically allied with economic growth and sustainable development. The education sector of Southern Punjab (Pakistan) is enduring from many blockades and the most imperative of them is gender discrimination. Females are not only underprivileged of their indispensable educational right but they have to do the household chores. Although different policies has been made to abolish gender discrimination but mostly they are quantitative rather than qualitative and they concentrate on the issues like family earnings, safe travelling, legal frameworks, high expectations related with girls education, lack of opportunity structures for girls education and rigid cultural norms attached with girls education. Two areas of gender disparity are low quality education and limited access of girls to education sector. The researcher concluded that education spending by government is very low and the policy making to close the gender gap is inadequate to meet the needs of quality education for girls. Female education contributes towards family welfare, socio-economic development and augmented productivity. Education disparity is the foremost stumbling block for squat female participation in the workforce for the development of the country. Other blockades for education of girls are barriers to access and equality, quality barriers, family barriers, poverty, household and community attitude and issues of security for girls' education. 


\section{Policy implications:}

1. Government should embark upon the cultural constraints that are related to social exclusion of girls from education sector like gender discrimination, gender isolation, gender violence and conflict through community action.

2. Government should establish separate schools for girls so that persistent cultural practices do not become stumbling block for girls education.

3. Government should focus its attention on gender inequality by means of advocacy and better research.

4. Government should launch such programmes that can address rigid cultural patterns such as prejudice, low status of women in social, economic, political and cultural sphere, negative propaganda by religious leaders, patriarchal structure of society, enslavement of the women on men, constrained involvement of girls in decision making process, restricted movement of girls, mute girlhood, security concerns for girls and cultural biasness for girls education.

5. Government should launch such programmes that can lessen the outcomes of gender role stereotypes associated with girls education.

6. Government should launch such programmes that can endorse education and economic interest of backward areas for the purpose of realizing the importance of girls education.

7. Policy makers should not disregard the cultural richness and diversity which is the major factor of policy success in education sector of Pakistan.

8. Government should endorse post primary education for girls through fiscal incentives.

9. Quality of education can be augmented by making it an outcome based education which should be based on equivalent participation of girls in education sector.

10. Government should make efforts to eradicate gender biasness related with teachers appointment so that they can also contribute their services in education sector.

11. Government should address the issues of cultural and social constraints related to girls education like gender discrimination, gender isolation, gender violence and conflict through community participation.

12. Government should allocate funds on the equivalent basis to education sector without the discrimination of rural and urban areas.

13. Government should allocate ample budget to education sector to facilitate the quality learning outcomes for girl's education. 


\section{References}

Abu-Ghaida, D. and S. Klasen. 2004. "The Costs of Missing the Millennium Development Goals on Gender Equity.” World Development, Vol.32, No.7, pp.1075-1107.

Addy, E.S. 2008. "Gender Equality in Juniors and Senior Secondary Education in Sub-Saharan Africa." The International Bank for reconstruction and development. The World Bank.

Akram, M. and Khan, F.J. 2007. "Public Provision of Education and Government Spending in Pakistan.” PIDE Working Papers, Islamabad, Pakistan.

Aly, J.H. 2007. "Education in Pakistan: A White paper (Revised). Documentation to debate and finalize the National Education Policy. Islamabad: Government of Pakistan, National Education Policy Review Team.

Andrabi, T. , J. Das, A.I. Khawaja, T. Vishwanath, T. Zajonic and the LEAPS Team. 2007. "Pakistan: Learning and Educational Achievements in Punjab Schools (LEAPS): Insights to Inform the Education Policy debate." Islamabad: World Bank. http//go.worldbank.org/YUFOT05SAO. Retrieved on 20-8-2009.

Aslam, M. 2009. "The Relative Effectiveness of Government and Private Schools in Pakistan: Are Girls Worse Off?” Education Economics, Vol.17, No.3, pp.329-354.

Benson, L. 2004. "Education and Social Mobility among Minority Population in Xinjiang. In: Starr, S.F. (Ed.). Xingiang: China Muslim Borderland. M.E. Sharpe, New York.

Boyle, S.A., J. Mace, M. Sibbons. 2002. "The Costs of Sending Children to School: A

Six-Country Comparative Study, Synthesis Report, Education Research Papers 12830. Department of International development (DFID), UK.

Chaudhry, M.A. 2005. "Where and who are the Worlds Illiterates?" Background Paper prepared for the Education for all Global Monitoring Report 2006 Literacy for Life. UNESCO. Retrieved on 15-4-2010.

Chitrakar, R. 2007. "Overcoming Barriers to Girls Education in South Asia." United Nations Child Fund. Education for All. Regional office of South Asia, Nepal.

Economic Survey of Pakistan. 2010. "Education" Government of Pakistan. Ministry of Finance. www.finance.gov.pk.

Edmont, J.M. and J. Robinson. 2000. "Is Child labor Inefficient." Journal of Political Economy, Vol. 108, No. 4, pp. 663-679.

Fuller, G.E., J.N. Lipman. 2004. "Islam in Xinjang. In: Starr, S.F. (Ed.). Xinjiang: China Muslim Borderland. M.E. Sharpe, New York.

Glandney, D.C. 2004. "Dislocating China. Muslims, Minorities and other Subaltern Subjects. Hurst and Company, London.

Glick, P. and Sahn, D.E. 2000. "Schooling of Girls and Boys in West African country: The Effects of Parental Education, Income and Household Structure." Economics of Education Review, Vol.19, No.1, pp.63-87.

Heise, L. , M. Ellsberg and M. Gottemoeller. 1999. "Ending Violence Against Women: Population Reports. Vol.27, No.4. Population Information Programmes, Center for Communication Programmes, The John Hopkins University.

Iredale, R., Guo, F. 2004. "Overview of Minority migration. In: Iredale, R., Bilik, N., Guo, F. (Eds.). China's Minorities on the Move: Selected Case Studies, M.E. Shape, New York. 
Jam, S.C. 2005. "Education and Socio-Economic Development." Ashok Kumar Mittal Concept Publishing Company, New Delhi, India.

Jejeebhoy, S.J. and Sathar, Z. 2001. "Women's Autonomy in India and Pakistan: The Influence of Religion and Region. Population and Development Review, Vol. 27, pp. 688-712.

Joshua, M.T., A.M. Joshua, A.W. Kritsonis. 2006. "Use of Students Achievement Scores as Basis for Accessing Teachers Institutional Effectiveness: Issues and Research Results. National Forum of Teachers Education Journal, 17 (3): 1-13.

Kabeer, N. 2005. "Gender Equality and Women Empowerment: A Critical Analysis of Third Millennium Development Goal." Gender and Development, Vol. 13, No. 1, pp. 13-24.

Khalid, H.S. and E.M. Mukhtar. 2002. "The Future of Girls Education in Pakistan." UNESCO Office, Islamabad, Pakistan.

Klasen, S. 2002. "Low Schooling for Girls, Slower Growth for All? Cross Country evidence on the Effect of Gender Inequality in Education on Economic Development." The World Bank Economic Review, Vol.16, No.3, pp.245-373.

Lloyd, C.B. , C. Mete and Z.A. Sathar. 2005. "The Effect of Gender Differences in Primary School Access, Type and Quality on the Decision to Enroll in Rural Pakistan." Economic Development and Cultural Change, Vol.53, No.3, pp.685-710.

Lloyed, C.B. , C. Mete, and M.J. Grant. 2009. "The Implications of Changing Educational and Family Circumstances for Children's Grade Progression in Rural Pakistan: 1997-2004." Economics of Education Review, Vol.28, No. 4, pp.152-160.

Lyned, D. R. 2007. "The Education System of Pakistan: Assessment of the National education census.” Published by UNESCO, Islamabad.

Mahbub-ul-Haq. 2000. “The Gender Question: Human Development in South Asia.” Human Development Center, Oxford University Press,2000.

Mishra, R.C. 2005. "Women Education.” New Dehli: A.P.H. Publishing Corporation.

National Assessment Findings, 2007: Mathematics and language, Grade 8, National Education Assessment System, Ministry of Education Government of Pakistan, 2006.

National Education Census: Highlights, Ministry of Education, Government of Pakistan, 2006.

National Education Policy, 2009. Government of Pakistan, Ministry of Education, Islamabad. www.moe.gov.pk.

Pakistan Social and Living Standard Survey, (PSLM). 2006-07. Ministry of Economic Affairs and Statistics, 2008. Government of Pakistan.

Pakistan Social and Living Standards Measurement (PLSM) Survey. 2008-2009. Federal Bureau of Statistics, Pakistan. Retrieved on 16-4-2010.

Pakistan Social and Living Standards Measurement (PSLM) Survey 2006-2007, Federal Bureau of Statistics, Pakistan.

Qureshi, R. and Rarieya, F.A. (eds). 2007. "Gender and Education in Pakistan.” Karachi: Oxford University Press.

Qureshi, S. 2004. "Pakistan: Education and Gender Policy for Girls Education: A Lifetime to Development." International Policy Fellowship 2003-2004, Center for Policy Studies. Retrieved on 13-3-2010.

Shami, D.P.A. , I. Fazeelat, K.S. Hussain. 2005. "Development of Education in Pakistan." Academy of Educational Planning and Management, ministry of Education, Islamabad. 


\section{Macrothink

Shaukat, A. 2009. "Delivering Girls Education in Pakistan." Oxfam GB Discussion Document.

Stephen, K. 2002. "Does Gender Inequality Reduce Growth and Development? Evidences from Cross Country Regressions." World Bank Policy Research report Working Paper Series No. 7.

UNESCO, 2010. "Why Gender equality in Basic Education in Pakistan." Published by UNESCO, Islamabad, Pakistan.

UNESCO. "2006. "Barriers to Inclusive Education." http://www.unescobkk.org/education/appeal/programme-themes/inclusive-education/thematic -issues/barriers-to-inclusive-education. Retrieved on 18-4-2010.

UNESCO. 2008. "Global Monitoring Report, 2009. Overcoming inequality. Why Governance Matters?" Paris. UNESCO/Oxford University Press.

Vachon, P. 2007. "Burkina Faso Country Case Study, Country Profile Prepared for Education for All Global Monitoring Report 2008-Education for All by 2015: Will we Make it? UNESCO, Paris.

Verma, M. 2006. "Gender in Girls and Women education." New Delhi: Murrai lal \& Sons.

Wolfe, B. and S. Zuvekas. 1997. "Non-Market Outcomes of Schooling." International Journal of Educational Research, Vol.27, No.6, pp.491-502.

XU, L.L., M. Jaschock. 2009. "Qiayi, A Preliminary Study of Uyghur Xingiang Women Minzu Yaniju (Nationality Research). Chinese Academy of Social Sciences, Beijing. 